\title{
Administration of Land Register in South Minahasa Regency
}

\author{
Marthinus M. Mandagi* \\ State Administration Study Program \\ Faculty of Social Sciences, \\ Universitas Negeri Manado \\ Manado, Indonesia \\ marthinusmandagi@unima.ac.id
}

\author{
Jeane Mantiri \\ State Administration Study Program \\ Faculty of Social Sciences \\ Universitas Negeri Manado \\ Manado, Indonesia \\ jeanelitha@unima.ac.id
}

\begin{abstract}
This study aims to describe, interpret and analyze the Performance of Village Apparatuses in the administration of the Land Register in South Minahasa Regency. The research method used is a qualitative method. The research site is located in South Minahasa Regency. The results found were the services provided by the South Minahasa District apparatus were seen to be unsatisfactory to the community in view of the lack of socialization, the realization of the main tasks and functions of each village apparatus and also the implementation of several regulations governing land registers.
\end{abstract}

Keywords: South Minahasa Regency, Administration, Performance

\section{INTRODUCTION}

Republic of Indonesia Government Regulation No. 24 of 1997 Article 1 number 1 PP Land Registration states that: Land registration is a series of activities carried out by the government on an ongoing and regular basis, including the collection, processing, accounting and presentation and maintenance of physical and juridical data, in the form of maps and lists, regarding plots of land and housing units, including the granting of proof of rights to existing plots of land, rights and ownership rights to housing units and certain rights which burden them.

Land in the legal sense has a very important role in human life because it can determine the existence and survival both in terms of individuals and for others. To prevent land problems from causing conflicts of interest in the community, it is necessary to regulate, control and use of land, or in other words called land law. One of the main objectives of the enactment of Law Number 5 of 1960 concerning Basic Regulations on Agrarian Principles (UUPA) is to realize legal certainty regarding land rights for all Indonesian people.

There are two attempts to realize the legal certainty, namely:

1. Provide written, complete and clear legal instruments.

2. Carrying out land registration that allows for holders of land rights to prove the rights to the land under their control and for the government to implement land policies.

Regarding land registration, it is regulated in Article 19 of the BAL. Land registration according to Article 19 paragraph (2) of the LoGA includes:
1. Measurement, mapping and accounting of land

2. Registration of land rights and transfer of rights.

3. Granting proof of rights, which acts as a strong proof.

Provisions regarding land registration are further regulated in Government Regulation Number 10 of 1961 concerning Land Registration (PP 10/1961). PP 10/1961 is deemed unable to provide satisfactory results, so it needs to be refined and replaced with Government Regulation Number 24 of 1997 regarding Land Registration (PP of Land Registration).

In implementing these provisions, Law Number 5 of 1960 Concerning Basic Agrarian Principles (UUPA) was made. With the LoGA regulation, it means that since then Indonesia has had a National Agrarian Law which is a legacy of independence after the Dutch colonial rule [1]. Land has a very important role, meaning that in the life of the Indonesian Nation or in the implementation of national development which is held as an ongoing effort to create a just and prosperous society based on Pancasila and the 1945 Constitution. Village government apparatus is an element that must exist in the administration of the village. which includes the village head and village apparatus (village secretary, affairs chief and hamlet head). One of the tasks of the village government apparatus is to provide public services in the field of administration and so on.

In line with that, according to Minister of PAN PAN No.63 / KEP / M.PAN / 7/2003 public services are all activities carried out by public service providers in an effort to meet the needs of service recipients and the implementation of statutory provisions. Village government parameters are wrong a driving force in village governance. The existence of the apparatus in the village government as executing administration and providing services to the community which is the object of service. The administration of the village government is a subsystem of the government administration system, so that the village government has the authority to regulate and manage the interests of the community. Public services by the government apparatus today still have many weaknesses so that they cannot meet the quality expected by the community. This is due to the fact that there are still a variety of public complaints submitted so as to cause an unfavorable image of the performance of the government apparatus related to the services provided [2]. Considering the main function of the government apparatus is serving the community, the government continues to strive to improve the quality of service. 
Regulation of the Minister of Home Affairs of the Republic of Indonesia NO. 47 Year 2016 Regarding Village Administration:

1. The administration of the village administration as referred to in article 3 is carried out through:

a. An orderly recording of data and information in the village register's book_book.

b. Development of village register books as well as conducting reports in accordance with statutory provisions.

2. Implementation and development of village government administration through an orderly recording of data and development of village register books as referred to in paragraph 1 is adjusted to the needs, the level of development of the village government and the complexity of the problems encountered in recording data and information on various activities.

In line with the above matters, the writer can take the problem of South Minahasa Regency because the Apparatus Performance in providing services to the community is seen to be not optimal / good in the arrangement of the Land Register, seen from the performance of the village apparatus that has not been fully able to provide satisfaction for the community, including some community lands that has been measured but not included in the land register book, which should be after the soil measurement is done must be included in the land register book. Administrative costs in measuring land vary from one community to another and also there are still many people who do not know about the importance of the land register because there is no socialization from the village government apparatus regarding land registers.

These things can lead to problems or land disputes and lead to legal conflicts that originate from complaints of a party (person / legal entity) that contains objections and demands for land rights that are not appropriate, both to the status of the land, priorities, and ownership. with the hope of obtaining administrative settlement in accordance with applicable regulations.

Based on the background description above, the problem found is How is the Performance of Village Apparatuses in the Administration of Land Registers in South Minahasa Regency in accordance with Indonesian Minister of Home Affairs Regulation NO 47 of 2016 concerning Village Government Administration?

\section{RESEARCH METHODS}

\section{A. Research Approach}

The research approach used in this study is a qualitative method because the results of research data are more relevant to the interpretation of data found in the field. Qualitative Research Methods are often called naturalistic research methods because the research is conducted in natural conditions (natural setting) [3].

\section{B. Research Locations}

Research time is estimated at 3 months. The location for conducting this research is in South Minahasa Regency. The reason the author chose this location, because the Administration of Land Registry in this village is an interesting thing to be studied and developed to be examined further.

\section{Research Instruments}

In this qualitative study the researcher acts as the Main Instrument that must actively go into the field by himself to conduct observations or research in stages at the research location [5].

\section{Data Sources}

In this study, the source of the data used is by taking a purposive sampling technique by selecting informants who really know the problem to be examined. So that this technique will make it easier for researchers to get satisfying results [3].

The source of the data in this study, namely:

1. Informant

To get effective data collection, the researchers directly held a meeting and established good communication with people who know clearly the social conditions that occur. In this case the informants determined purposively are the Village Head, Government Apparatus and the Community.

2. Social Situation

Done by taking data based on the situation situation to be made a support in conducting this research.

3. Document

Documents intended in this study are documents that are relevant to this research, such as the register of land owned by the community and other regulations relating to the policy of the village apparatus in administering land registers, which can provide information and support the author in the research process.

\section{Data Validity Test}

To determine the validity of the data in qualitative research must meet several requirements in the examination of data using 4 criteria, namely [3]

1. Credibility

This criterion serves to carry out the inquiry in such a way that the level of confidence in the findings can be achieved, demonstrating the degree of trust in the findings by proving by the researcher to the multiple facts being investigated.

2. Dependability

This method is used to conduct an audit by auditing the entire research process again.

3. Comfirmability

Conducted by conducting a careful examination of all components as well as the results of research conducted. This examination is carried out continuously so as to obtain conclusions from the results of research.

\section{RESULTS AND DISCUSSION}

A. Performance of Village Apparatuses in Administration of Land Registers in South Minahasa Regency 
Research on Apparatus Performance in Administration of Land Registers in South Minahasa Regency researchers used a measuring indicator that will be used as a knife for analysis in this study [4]. Performance is the level of achievement of objectives. Administration is a business and activity relating to the implementation of policies to achieve goals. Administration in the strict sense is an activity which includes: notes, correspondence, light bookkeeping, typing, agenda, and so on which are technical in administration. Administration in a broad sense is the whole process of cooperation between two or more people in achieving their goals by utilizing certain infrastructure in an efficient and effective manner. Performance is related to good, poor results, while administration is concrete and must realize what is desired. The discussion on Performance in administration is how to link the two, how are the ideas of Administration as follows: (1) Productivity, (2) Service Quality, (3) Responsiveness, (4) Responsibility, (5) Accountability.

\section{Productivity}

Productivity is a measure of service effectiveness but what happens in South Minahasa Regency is that some people are not satisfied with the performance of the apparatus in arranging land registers in South Minahasa Regency because the services provided to other communities are different from those provided to other communities, according to the informant " DM "that is some measured community land that is subject to administrative costs that are different from other communities. As we experienced, we paid Rp. 500.000 per field (kintal) while others only Rp. 300.000 and others. This makes us feel not satisfied with their performance.

Even the educational background is an inhibiting factor for the apparatus to provide excellent service for all people, because education or knowledge possessed by the apparatus greatly supports the success of a goal to be achieved that results in satisfaction for the community in managing land registers in South Minahasa Regency.

Productivity not only measures the level of efficiency but also measures the effectiveness of the service. Productivity is generally understood as the ratio between input and output.

\section{Quality of Service}

The quality of services that occur in South Minahasa Regency in the administration of land registers are not optimal, not in line with the expectations of both the apparatus themselves and the community because there are some members in the field of land measurement who do not know correctly about their main duties and functions (Tupoksi), services by The land registration administration apparatus is not optimal because, as I saw in the field when carrying out the task of measuring the head of the land gauge which should have the main role to carry out the task, not to carry out in accordance with the duties and functions. And also the land register has several empty columns, which occur in apparatus entrusted or previously assigned in the administration of land registers that should not be emptied. The village land register has several empty columns and we from the Team are not sure about the motive of emptying some of these columns, maybe because the land certificate is lost, the land certificate is wet and cannot be read, threats from other parties and there may also be intentional with certain purposes. It is better to eliminate or cover up the columns so that they will not cause problems or unwanted conflicts.

The things above greatly affect the quality of service personnel to create satisfaction for the community as a recipient of service. The quality of service is very desirable by both the service provider and recipient. Thus, public satisfaction with services can be an indicator of the performance of public organizations.

\section{Responsiveness}

Responsiveness is the ability of organizations to recognize community needs. And to find out the responsiveness of the apparatus to the needs of the community The performance of the South Minahasa Regency apparatus in administering land registers has not been fully evective and efficient. As stated by several informants, that is seen from the aspect of efficiency / our time as government and apparatus sometimes on time sometimes also not, yes because the majority of the population in South Minahasa Regency are farmers, and the apparatus in charge are yes, farmers ( capticus) so sometimes you have to divide your time. And from an evective point of view sometimes also mines, because when we are in the land measurement location there are things that are beyond our estimation, often have problems that make us unable to carry out our duties.

And also the service in South Minahasa Regency has not yet fully run well because from the results of research through interviews with the apparatus and the community it was found that very rarely / even no socialization about the legal basis used in the implementation of land register services in South Minahasa Regency. Socialization is very important because in addition to the public knowing the conditions in carrying out government duties in South Minahasa Regency must be in accordance with applicable laws and regulations.

\section{Responsibility}

Responsibility explains whether the implementation of public organization activities is carried out in accordance with the principles of administration that is correct or in accordance with organizational policies. In detail do not know but in general little know, because what happened in South Minahasa Regency has not been fully carried out according to the rules. Color is not a guidebook for us, there has been a guide but it is not carried out. We only carry out tasks according to the devices before us. However, in carrying out our duties we endeavor to have everything completed. Based on the results of interviews that researchers have obtained from the informants, it can be concluded that, the implementation of PP RI No. 24 of 1997 concerning land registration has not been realized properly. And also land register services that do not yet exist in village regulations. According to the results of the interview, the researcher draws the conclusion that the apparatus appointed by the leadership in carrying out their duties is the apparatus that carries out the tasks not in 
accordance with the responsibilities given based on TUPOKSI and SOP.

\section{Accountability}

Responsibility is to carry out duties and work in accordance with the terms and conditions agreed to be carried out. Responsibilities in public services include leaders who provide services to the public or designated officials responsible for service delivery and resolution of problems and complaints in give service. Cost standards that must be implemented in the field must be in accordance with the same cost standards as established government regulations. Based on interviews with several informants namely the difference in costs that must be paid by one community with other communities, as the informant said "DM" namely: Administration of Rp. 500,000 per field, because we have taken measurements of land and administration that we have to give Rp. 1,000,000 incidentally two plots of land. In contrast to what the "J.O" informant said, which is the administration of Rp. $300,000-500,000$ per field, because we have taken measurements of land and the administration we have to give is Rp. 3,000. This must be held accountable from service providers as public officials. And also problem solving in the administration of land registers that must be resolved by public officials as accountability. The loyalty of the apparatus determines the success of the organization, and according to some informants who are asked for information that the apparatus in the South Minahasa Regency is loyal to the leader because loyalty is part of the work accountability.

The performance of public organizations is not only seen from the internal measures developed by public organizations or governments such as the achievement of targets, but also must be assessed from external measures such as values and norms prevailing in society. An activity of a public organization has high accountability if the activity is considered true and in accordance with the values and norms that develop in society.

\section{CONCLUSION}

Based on the results of research and discussion that has been analyzed that has been described in the previous chapter, it is obtained several conclusions that can be outlined in the study of the Performance of the Village Apparatus in the Administration of Land Registry i in South Minahasa Regency, among others:

1. The services provided by the South Minahasa District apparatus seem unsatisfactory to the community in terms of the lack of socialization, the unfulfilled of the main tasks and functions of each village apparatus and also the implementation of several regulations governing land registers. And these things that make the services provided by village officials in the arrangement of land registers are ineffective.

\section{ACKNOWLEDGMENT}

High appreciation and gratitude to the Dean of Social Science Faculty Manado State University, IJCST 2020 committee and publisher.

\section{REFERENCES}

[1] G. of Indonesia, Law No. 5 of 1960 concerning Basic Rules of Agrarian Principles. 1960.

[2] J. Mantiri and C. M. Siwi, "THE ROLE OF THE GOVERNMENT AS THE KEY KEY TO MANAGING VILLAGE FUNDS IN THE VILLAGE OF PAMONA DISTRICT, PAMONA PUSELEMBA, POSO PROVINCE, CENTRAL SULAWESI DISTRICT," J. Civ. Educ. Kaji Media. Pancasila and Citizenship, 2018

[3] Sugiyono, Combined Research Methods (Mixed Methods). 2010

[4] Y. T. Keban, "Principal Thoughts on Improving Civil Servant Management System in Indonesia," J. Kebijak. and Adm. Public, 2004.

[5] Pasolong, Public Administration Theory, Yogyakarta: Alfabeta. 2012.

[6] Republic of Indonesia Government Regulation No. 24 of 1997 concerning Land Registration.

[7] Republic of Indonesia Minister of Home Affairs Regulation NO 47 of 2016 concerning Village Government Administration.

[8] Decree of the Minister of Administrative Reform No. 63 / KEP / M.PAN / 7/2003 concerning General Guidelines for the implementation of Public Services. 